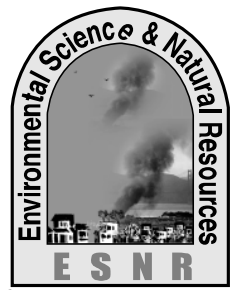

\title{
Short Term Red Amaranth Growth With Urea as N Source
}

\author{
M. Y. Miah ${ }^{1}$, M. R. Das ${ }^{2}$ and J. Hassan ${ }^{3}$
}

${ }^{1}$ Dipartment of Soil Science, ${ }^{2}$ Department of Crop Botany, ${ }^{3}$ Department of Horticulture, Banghobondhu Shekh Mogibur Rahman Agriculture University, Gazipur-1706

\begin{abstract}
The study was conducted at the farm of Banghobondhu Shekh Mogibur Rahman Agriculture University, Gazipur during the period of November to December, 2010 to enhance the production of red amaranth (Amaranthus tricolor cv: BARI lal shak 1) through the improvement of growth and yield of red amaranth by optimizing the appropriate levels of nitrogen fertilizer. The experiment was laid out in a Randomized Complete Block Design (RCBD) comprising six treatments with four replication each. The treatment combinations were $\mathrm{T}_{0}\left(0 \mathrm{~kg} \mathrm{~N} \mathrm{ha}^{-1}\right), \mathrm{T}_{1}\left(50 \mathrm{~kg} \mathrm{~N} \mathrm{ha}^{-1}\right), \mathrm{T}_{2}\left(75 \mathrm{~kg} \mathrm{~N} \mathrm{ha}^{-1}\right), \mathrm{T}_{3}\left(100 \mathrm{~kg} \mathrm{~N} \mathrm{ha}^{-1}\right), \mathrm{T}_{4}\left(125 \mathrm{~kg} \mathrm{~N} \mathrm{ha}^{-}\right.$ $\left.{ }^{1}\right)$ and $\mathrm{T}_{5}\left(150 \mathrm{~kg} \mathrm{~N} \mathrm{ha}^{-1}\right)$, respectively. Amounts of $\mathrm{N}, \mathrm{P}, \mathrm{K}$ and $\mathrm{S}$ applied from urea, TSP, MOP and gypsum were 68, 23, 17 and 4 $\mathrm{kg} \mathrm{ha}^{-1}$, respectively. Data on plant height, leaf number, root-shoot growth and dry weight along with yield and BCR (benefit cost ratio) indicated that urea applied at the rate of $150 \mathrm{~kg} \mathrm{~N} \mathrm{ha}^{-1}$ had a significant $(\mathrm{p}<0.01)$ effect on the short term growth and yield of red amaranth.
\end{abstract}

Key words: Red amaranth, Short Growth Period, Urea, Yield

\section{Introduction}

In general, red amaranth (Amaranthu tricolor) belonging to the family Amaranthaceae is a delicious vegetable with its considerable nutritional value around the globe and in particular, in parts of tropical and subtropical Asia, Africa and Central America. However, Chiefly grown during summer and rainy season, amaranth is an important and popular vegetable in Bangladesh because of its cheapest price, quick growing character and higher yield potential (Hossain, 1996). Therefore, in Bangladesh context, it is considered as a potential upcoming subsidiary food crop (Teutonic and Knorr, 1985). Simultaneously, the leaves and stems of amaranth are rich in protein, fat, calcium, phosphorus riboflavin niacin, sodium, iron and ascorbic acid. Additionally, it contains 43 food caloric which is higher than any other vegetables except potato and tomato (Chaudhury, 1967 and FAO, 1972). A part from this, it is processed into table products like soup. Even it seeds are used in making sweet rolls, crepes cookies crackers, etc. (Muthukrishan; Irulappan, 1986; Shanmugavelu, 1989). However, in Bangladesh, its cultivation is increasing day by day (BBS, 2010) although its production is lower than other amaranth producing countries (Talukder, 1999). Mean while, in Bangladesh, nitrogen fertilizer is the most crucial input for crop production and had been recognized as the central element for agricultural production as it imparts a major role on the increase of quality, color and taste of vegetables (Monira, 2007). Available reports also indicate that chemical fertilizers specially the nitrogenous ones are not applied in balanced proportions (Anonymous, 1997) for vegetable production. Additionally, information on the use of appropriate levels of nitrogen fertilizer with particular reference to red amaranth cultivation under specific agro-climatic conditions for short term growth period is lacking in general. These facts suggest that there is an ample scope of increasing red amaranth production with the appropriate use of nitrogen fertilizers. So the experiments presented in this article were conducted to evaluate the contributions of urea on plant height, leaf number, length, breadth, rootshoot growth and yield encompassing BCR as regards of short term growth period.

\section{Materials and Methods}

The study was conducted at the farm of BSMRAU campus, Gazipur, Bangladesh during NovemberDecember, 2010 in the agro-ecological zone (AEZ 28) of Modhupur tract representing shallow red brown terrace soil. Determined by the methods of Miah et al. (1998), the soil characters of the experimental site were silty clay loam having a $\mathrm{pH}$ (5.5), total nitrogen $(0.054 \%)$ and organic matter $(1.38 \%)$. The experiment was laid out in a Randomized Complete Block Design (RCBD) comprising the treatment combinations $\mathrm{T}_{0}$ (No nitrogen $), \mathrm{T}_{1}\left(50 \mathrm{~kg} \mathrm{~N} \mathrm{ha}^{-1}\right), \mathrm{T}_{2}\left(75 \mathrm{~kg} \mathrm{~N} \mathrm{ha}^{-1}\right), \mathrm{T}_{3}(100$ $\left.\mathrm{kg} \mathrm{N} \mathrm{ha}^{-1}\right), \mathrm{T}_{4}\left(125 \mathrm{~kg} \mathrm{~N} \mathrm{ha}^{-1}\right), \mathrm{T}_{5}\left(150 \mathrm{~kg} \mathrm{~N} \mathrm{ha}^{-1}\right)$ with urea as $\mathrm{N}$ source and replicated four. Opened with a tractor, the land was ploughed and cross-ploughed for several times with a power tiller followed by laddering to bring the soil under good tilth conditions. However, P, K, and S at 23.0, 17.0 and $4.0 \mathrm{~kg} \mathrm{ha}^{-1}$ were applied from TSP, MP, and gypsum, respectively during final land preparation. In contrast, nitrogen doses were top dressed at two equal installments at 10 and 25 days after sowing (DAS), respectively. The prepared block consisted of 24 plots where unit plot size, plant accommodation and intercultural operations were maintained by the methods of Choudhury et al. (1974) and Waseem and Nadeem (2001). To check insect attack, Malathion 57 EC was applied at $2 \mathrm{~mL} / \mathrm{L}$ fortnightly. Irrigations 
were given by watering cane if and when needed. Data on plant height, number of leaves along with length and breadth, root-shoot growth accompanied with dry and fresh weights, yield of red amaranth were recorded from eight plants being randomly selected from each plot encompassing the avoidance of boarder effect and statistical analyses were performed by the method of Gomez and Gomez (1984). Simultaneously BCR based profitability was assessed.

\section{Results and Discussion}

\section{Plant height}

Red amaranth plants grew well during entire growing period. Heights of the plants were recorded from all of $\mathrm{T}_{0}, \mathrm{~T}_{1}, \mathrm{~T}_{2}, \mathrm{~T}_{3}, \mathrm{~T}_{4}$ and $\mathrm{T}_{5}$ treatments (Table 1). The application of different treatment combinations comprising various $\mathrm{N}$ levels affected plant height significantly $(\mathrm{p}<0.01)$. The highest plant height $(25.93 \mathrm{~cm})$ was recorded in treatment $\mathrm{T}_{5}$ followed by treatment $\mathrm{T}_{4}(21.77 \mathrm{~cm}), \mathrm{T}_{3}(20.99 \mathrm{~cm}), \mathrm{T}_{2}(20.78$ $\mathrm{cm}), \mathrm{T}_{1}(17.15 \mathrm{~cm})$ and $\mathrm{T}_{0}(11.33 \mathrm{~cm})$, respectively. Obtained results on plant height were similar to those reported by Hamid et al. (1989) and Roy (2008).

\section{Leaf number, length and breadth}

As shown in Table 1, various treatment combinations induced differences among the number of leaves produced (per plant) were significant $(\mathrm{p}<0.01)$. The highest leaf number (24.66) was found in treatment $\mathrm{T}_{5}$ and the lowest leaf (14.37) number was obtained in
$\mathrm{T}_{0}$. In the current experiment, recorded data on the number of red amaranth leaves (per plant) were in full agreement with those of Talukder (1999). As for leaf length, significant $(\mathrm{p}<0.01)$ variation was recorded in different treatment combinations (Table 1). The longest leaf length $(7.46 \mathrm{~cm})$ was measured in $T_{5}$ and that of the lowest leaf length $(4.12 \mathrm{~cm})$ was recorded treatment $\mathrm{T}_{0}$. Meanwhile, the breath of the leaves of the plant differed significantly $(\mathrm{p}<0.01)$ among the various treatment combinations (Table 1). The highest leaf breadth $(5.41 \mathrm{~cm})$ was measured in treatment $T_{5}$. On the contrary, the lowest leaf breadth $(3.29 \mathrm{~cm})$ was found in treatment $T_{0}$. Thus the data of red amaranth leaf length and breadth coincided with the findings of Hossain (1996) and Rajgopal et al. (1977), respectively.

\section{Root length and shoot diameter}

The effect of different treatments on root length was not significant (Table 1). The longest root length $(6.48 \mathrm{~cm})$ was found in treatment $\mathrm{T}_{5}$ and the lowest $(5.76 \mathrm{~cm})$ was recorded in treatment $\mathrm{T}_{0}$. On the contrary, the application of different levels of $\mathrm{N}$ affected shoot diameter significantly $(\mathrm{p}<0.01)$. The highest shoot diameter $(3.94 \mathrm{~cm})$ was observed in $\mathrm{T}_{5}$ and that of the lowest $(2.55 \mathrm{~cm})$ was recorded in $\mathrm{T}_{0}$. These sorts of differential effects of various nitrogen levels on root and shoot growth patterns of amaranths were reported by Roy (2008), Hossain (1996) and Talukder (1999).

Table 1: Effect of $\mathrm{N}$ on vegetative growth of red amaranth

\begin{tabular}{|l|c|c|c|c|c|c|c|}
\hline Treatment & $\begin{array}{l}\text { Plant } \\
\text { height }(\mathrm{cm})\end{array}$ & $\begin{array}{l}\text { No. of } \\
\text { leaves } \\
\left(\mathrm{plant}^{-1}\right)\end{array}$ & $\begin{array}{l}\text { Leaf } \\
\text { breadth } \\
(\mathrm{cm})\end{array}$ & $\begin{array}{l}\text { Leaf } \\
\text { length } \\
(\mathrm{cm})\end{array}$ & $\begin{array}{l}\text { Root } \\
\text { length } \\
(\mathrm{cm})\end{array}$ & $\begin{array}{l}\text { Shoot } \\
\text { diameter } \\
(\mathrm{cm})\end{array}$ & $\begin{array}{l}\text { Fresh root } \\
\text { weight plant } \\
(\mathrm{g})\end{array}$ \\
\hline $\mathrm{T}_{0}$ & 11.33 & 14.37 & 3.29 & 4.12 & 5.76 & $\begin{array}{l}\text { Dry root weight } \\
\text { plant }\end{array}$ \\
\hline $\mathrm{T}_{1}(\mathrm{~g})$
\end{tabular}

$\mathrm{T}_{0}=0 \mathrm{~kg} \mathrm{~N} \mathrm{ha}^{-1}, \mathrm{~T}_{1}=50 \mathrm{~kg} \mathrm{~N} \mathrm{ha}^{-1}, \mathrm{~T}_{2}=75 \mathrm{~kg} \mathrm{~N} \mathrm{ha}^{-1}, \mathrm{~T}_{3}=100 \mathrm{~kg} \mathrm{~N} \mathrm{ha}^{-1}, \mathrm{~T}_{4}=125 \mathrm{~kg} \mathrm{~N} \mathrm{ha}^{-1}, \mathrm{~T}_{5}=150 \mathrm{~kg} \mathrm{~N}^{-1}$

$\mathrm{CV}=$ Co-efficient of variation

LSD = Least Significant Difference

NS $=$ Non-significant

$* *$ Significant at $1 \%$ level of probability

\section{Fresh and dry root weight}

There was significant $(\mathrm{p}<0.01)$ effect of different treatments on the production of fresh root weight of red amaranth (Table 1). As for fresh weight, the highest value $(0.96 \mathrm{~g})$ was observed in $\mathrm{T}_{4}$ and that of the lowest $(0.47 \mathrm{~g})$ was recorded in $\mathrm{T}_{0}$ and such pattern of fresh root weight production was similar to those of Talukder (1999). In contrast, the trend of dry weight production was insignificant and rugged in all of $\mathrm{T}_{0}, \mathrm{~T}_{1}, \mathrm{~T}_{2}, \mathrm{~T}_{3}, \mathrm{~T}_{4}, \mathrm{~T}_{5}$, respectively with the highest dry root weight $(0.091 \mathrm{~g})$ in $\mathrm{T}_{5}$ and that of the lowest $(0.041 \mathrm{~g})$ in $\mathrm{T}_{0}$ coinciding with those of Roy (2008). 


\section{Fresh and dry plant weight}

The effect of different treatments on plant fresh weight was significant $(p<0.01)$. As shown in Table 2 , highest fresh weight $(12.07 \mathrm{~g})$ was measured in $\mathrm{T}_{5}$ and that of lowest $(4.88 \mathrm{~g})$ was found in $\mathrm{T}_{0}$. These sorts of findings indicated that increase in nitrogen doses had a positive effect on the increment of plant fresh weight. On the other hand, increase in nitrogen dose had a significant $(\mathrm{p}<0.01)$ influence on the increase in plant dry weight too. Namely, a similar trend of highest $(0.74 \mathrm{~g})$ and lowest $(0.52 \mathrm{~g})$ dry weights were recorded in $\mathrm{T}_{4}$ and $\mathrm{T}_{0}$ treatments, respectively. In response to nitrogen fertilization, such patterns of fresh and dry plant weights for amaranths were reported by Roy (2008).

\section{Yield /plot}

As for yield in red amaranth, different treatments showed significant $(\mathrm{p}<0.01)$ variation (Table 2$)$. The results indicated that maximum yield (1333.33 g) per plot was observed in $\mathrm{T}_{5}$ and that of the lowest (350.0 g) was recorded in $T_{0}$. These high and low yields could be ascribed for the highest nitrogen dose application followed by that received no nitrogen because $\mathrm{N}$ is central element for the growth and development of plant (Roy, 2008).

Table 2: Effect of $\mathrm{N}$ on the yield attributes of red amaranth

\begin{tabular}{|c|c|c|c|c|}
\hline Treatment & Fresh weight $\left(\right.$ plant $\left.^{-1}\right)(\mathrm{g})$ & Dry weight $\left(\right.$ plant $\left.^{-1}\right)(\mathrm{g})$ & Yield $\left(\right.$ plot $\left.^{-1}\right)(\mathrm{g})$ & Yield $\left(\mathrm{t} \mathrm{ha}^{-1}\right)$ \\
\hline $\mathrm{T}_{0}$ & 4.88 & 0.52 & 350.00 & 0.87 \\
\hline $\mathrm{T}_{1}$ & 7.25 & 0.68 & 791.66 & 1.98 \\
\hline$T_{2}$ & 8.89 & 0.73 & 966.66 & 2.41 \\
\hline$T_{3}$ & 10.23 & 0.81 & 1100.00 & 2.75 \\
\hline $\mathrm{T}_{4}$ & 11.49 & 0.88 & 1200.00 & 3.00 \\
\hline $\mathrm{T}_{5}$ & 12.07 & 0.74 & 1333.33 & 3.33 \\
\hline CV (\%) & 4.11 & 10.30 & 1014 & 10.14 \\
\hline LSD & 0.68 & 0.14 & 176.50 & 0.44 \\
\hline $\begin{array}{l}\text { Level of } \\
\text { significance }\end{array}$ & $* *$ & $* *$ & $* *$ & $* *$ \\
\hline
\end{tabular}

$\mathrm{T}_{0}=0 \mathrm{~kg} \mathrm{Nha}^{-1}, \mathrm{~T}_{1}=50 \mathrm{~kg} \mathrm{~N} \mathrm{ha}^{-1}, \mathrm{~T}_{2}=75 \mathrm{~kg} \mathrm{~N} \mathrm{ha}^{-1}, \mathrm{~T}_{3}=100 \mathrm{~kg} \mathrm{~N} \mathrm{ha}^{-1}, \mathrm{~T}_{4}=125 \mathrm{~kg} \mathrm{~N} \mathrm{ha}^{-1}, \mathrm{~T}_{5}=150 \mathrm{~kg} \mathrm{~N} \mathrm{ha}^{-1}$

$\mathrm{CV}=$ Co-efficient of variation

LSD $=$ Least Significant Difference

$* *=$ Significant at $1 \%$ level of probability

\section{Yield /hectare}

Yield of red amaranth was positively influenced by various treatments (Table 2). However, variation among the treatments corresponding to red amaranth yield per hectare was significant $(\mathrm{p}<0.01)$. Generalized trend observed for yield was that yield per hectare increased with the increase in nitrogen dose $\left(T_{0}>T_{1}>T_{2}>T_{3}>T_{4}>T 5\right)$, respectively. The highest yield (3.33 t/ha) was found in $\mathrm{T}_{5}$ and the lowest yield $\left(0.87 \mathrm{t} \mathrm{ha}^{-1}\right)$ was recorded in $\mathrm{T}_{0}$ However, such results were in perfect agreement with those of Ara (2005).

\section{Economic performance of red amaranth}

The partial budget analysis on the effect of nitrogen doses applied on red amaranth production is presented in Table 3. The highest gross return (Taka 39,960.00 $\mathrm{ha}^{-1}$ ) was obtained from the treatment $\mathrm{T}_{5}$ which received $\mathrm{N}\left(150 \mathrm{~kg} \mathrm{ha}^{-1}\right)$, followed by the treatment $\mathrm{T}_{4}$ (Taka 36,000.00 ha ${ }^{-1}$ ) which received $\mathrm{N}(125 \mathrm{~kg}$ $\left.\mathrm{ha}^{-1}\right), \mathrm{T}_{3}$ (Taka $\left.33000.00 \mathrm{ha}^{-1}\right)$ which received N (100 $\mathrm{kg} \mathrm{ha}^{-1}$ ), $\mathrm{T}_{2}$ (Taka 28,900.00 ha ${ }^{-1}$ ) which received $\mathrm{N}$ $\left(75 \mathrm{~kg} \mathrm{ha}^{-1}\right)$ and $\mathrm{T}_{1}$ (Taka 23, $760.00 \mathrm{ha}^{-1}$ ) which received $\mathrm{N}\left(50 \mathrm{~kg} \mathrm{ha}^{-1}\right)$. All the treatments resulted in higher gross return over the control (Taka 10,440.00 $\mathrm{ha}^{-1}$ ). On the other hand, highest variable cost (Taka $10,980.00 \mathrm{ha}^{-1}$ ) was required in the treatment $\mathrm{T}_{5}$ which received $\mathrm{N}\left(150 \mathrm{~kg} \mathrm{ha}^{-1}\right)$ and that of the lowest (Taka 7479.00) was needed in $\mathrm{T}_{0}$ which received no nitrogen fertilizer. The highest cost benefit ratio (3.66) was recorded in $T_{4}$ which was followed by $T_{5}$ (3.64).

Table 3: Effect of nitrogen on economic performance of red amaranth cultivation

\begin{tabular}{|c|c|c|c|c|}
\hline Treatment & Gross return $\left(\right.$ Tkha $\left.^{-1}\right)$ & TVC $\left(\right.$ Tkha $\left.^{-1}\right)$ & Gross margin $\left(\right.$ Tkha $\left.^{-1}\right)$ & BCR \\
\hline $\mathrm{T}_{0}$ & 10440.00 & 7479.00 & 2961.00 & 1.40 \\
\hline $\mathrm{T}_{1}$ & 23760.00 & 8507.00 & 15235.00 & 2.79 \\
\hline $\mathrm{T}_{2}$ & 28920.00 & 9211.00 & 19709.00 & 3.14 \\
\hline $\mathrm{T}_{3}$ & 33000.0 & 9544.00 & 23456.00 & 3.46 \\
\hline $\mathrm{T}_{4}$ & 36000.00 & 9826.00 & 26174.00 & 3.66 \\
\hline $\mathrm{T}_{5}$ & 39960.00 & 10980.0 & 28980.00 & 3.64 \\
\hline
\end{tabular}

$\mathrm{T}_{0}=0 \mathrm{~kg} \mathrm{~N} \mathrm{ha}^{-1}, \mathrm{~T}_{1}=50 \mathrm{~kg} \mathrm{~N} \mathrm{ha}^{-1}, \mathrm{~T}_{2}=75 \mathrm{~kg} \mathrm{~N} \mathrm{ha}^{-1}, \mathrm{~T}_{3}=100 \mathrm{~kg} \mathrm{~N} \mathrm{ha}^{-1}, \mathrm{~T}_{4}=125 \mathrm{~kg} \mathrm{~N} \mathrm{ha}^{-1}, \mathrm{~T}_{5}=150 \mathrm{~kg} \mathrm{~N}^{-1} \mathrm{~T}^{-1}, \mathrm{TVC}=$ Total

Variable Cost, $\mathrm{BCR}=$ Benefit Cost Ratio 


\section{Conclusions}

The results indicated that $\mathrm{N}$ doses had a positive impact on the growth parameters of red amaranth like plant height, leaf number, fresh and dry weight of plant. Additionally applied nitrogen had significant effect on yield and BCR too. But comparative results of various parameters studied in the present investigation suggested that $T_{5}$ was the best treatment because yield was highest $\left(3.33 \mathrm{t} \mathrm{ha}^{-1}\right)$ in $\mathrm{T}_{5}$ and related BCR in both of $\mathrm{T}_{4}$ and $\mathrm{T}_{5}$ treatment combinations were 3.66 and 3.64 , respectively with no considerable difference. However, the present study was conducted in winter season of 2010 at BSMRAU research farm only. Therefore, recommendation of $\mathrm{T}_{5}\left(\mathrm{~N} 150 \mathrm{~kg} \mathrm{ha}^{-1}\right)$ as fertilizer dose necessitates both regional and multi location trials. Finally yield followed by BCR suggests that treatment $\mathrm{T}_{5}$ had the potentials to be recommended as suitable $\mathrm{N}$ dose for short term red amaranth cultivation.

\section{References}

Anonymous, 1997. Fertilizer Recommendation Guide published by BRAC, Dhaka, Bangladesh.

Ara, R. 2005. Effect of nitrogen and harvesting frequencies on yield and quality of spinach. MS Thesis, Dept. of Hort., BSMRAU, Gazipur, Bangladesh.

BARC, 2008. Fertilizer Recommendation Guide, BARC, Farm gate, Dhaka, Bangladesh.

BBS, 2010. Yearbook of Agricultural Statistics of Bangladesh. Bangladesh Burea of Statistics. Statistics Division, Ministry of Bangladesh. Dhaka, Bangladesh, pp. 100-109.

Chaudhury, B. 1967. Vegetables. National Book Trust: New Delhi. India. P. 195.

Choudhury, A. R.; Rashid, M. M.; Hossain, A. 1974. A study on the effect of different spacing and nitrogen levels on the yield of spinach. Bangladesh Horticulture, 2: 39-43.

FAO, 1972. Food composition table for use in East Asia. UN and US Department of Health, Education and Welfare. pp. 11-15.

Gomez, K. A. and Gomez., A. A. 1984. Statistical Procedure for Agricultural Research, John Willey and Sons, New York.
Hamid, M. M.; Ahmed, N. U. and Hossain, S. M. M. 1989. Performance of some local and exotic germplasm of amaranth. Agril. Sci. Digest, 9 , 202-204.

Hossain, S. I. 1996. A comparative study on yield and quality of some Amaranth genotype. MS thesis, IPSA, Salna, gazipur, pp 41-44.

Miah, M. Y.; Kanazawa, S and Chino, M. 1998. Nutrient distribution across wheat rhizosphere with oxamide and ammonium sulfate as N source. Soil Sci. Plant Nutr., 44: 579-587.

Monira, U. M. 2007. Nutrient status in tomato grown on organic manure treated soil. MS thesis, Dept. of Soil Science, BSMRAU, Salna, Gazipur.

Muthukrisna, C. R. and Irulappan, I. 1986. Amaranthus. pp. 670-679. In: Bose, T.K. and Som, M.G. (eds.) Vegetable crop in Indian. Naya Prokash, Calcutta-6. India.

Rajgopal, A.; Muthukrishan, C. R.; Mohideen, M. K. and Syed, S. 1977. 2 amaranths-An early vigorous variety. South Indian J. of Agric. Sci., 50(2), 183-186.

Roy, P. K. 2008. Effect of organic manures on growth and yield in stem amaranth. MS thesis, Dept. of Soil Science, BSMRAU, Gazipur.

Shanmugavelu, K. G. 1989. Amaranthus. In: production Technology of vegetables Crops. Oxford and IBH Publishing Co Pvt. Res. Cent., USDA, Albary, California, USA.

Talukder, M. S. A. 1999. Effect of plant density on green yield and seed production in different amaranths. MS Thesis, BSMRAU, Salna, Gazipur.

Teutonico, R. A and Knorr, D. 1985. Amaranth composition, properties and application of a reddish covered food crop: Food technology, 39: 49-61.

Wasem, K. and Nadeem, A. 2001. Enhaance of spinach production by varying sowing dates, row spacing and frequencies of cuttings. On line J. Bio. Sci., Asian Network for Scientific Information, 1:92-94. 